\title{
Plasma apolipoprotein VLDL-II and egg production in laying hens: establishment of an ELISA method
}

\author{
Y Pinchasov, S Elmaliah, S Bezdin \\ Department of Animal Science, Faculty of Agriculture, The Hebrew University of Jerusalem, \\ Rehovot 76-100, Israel
}

(Received 14 February 1994; accepted 20 May 1994)

\begin{abstract}
Summary - The developmental pattern of apolipoprotein VLDL-II (apo-II) in the plasma with regard to lipid concentration was characterized during the transition of pullet females to the laying phase in commercial laying hens (Gallus domesticus). Apo-II was isolated from the plasma of estrogen-administered roosters, and a rapid ELISA was developed for its quantification in chickens. The sensitivity of the assay was $5 \mathrm{ng} / \mathrm{ml}$, and the inter- and intra-assay coefficients of variation were 4 and $8 \%$, respectively. Whereas no detectable levels of apo-II could be monitored in the blood plasma of immature chickens, the level increased slightly to 23 weeks of age and sharply at the onset of lay. This profile reflects the dramatic changes in lipid metabolism at the onset of lay, and concurs with the concentration of total lipids in the plasma and with egg production rate. Plasma apo-II of 2 laying strains differing in body weights but compared at approximately similar egg production rates, tended to be slightly higher in heavy vs light-weight type hens. Oogenesis was speculated to be the main factor affecting both apo-II and total lipid profiles in chicken plasma, enabling efficient delivery of VLDL to the egg.
\end{abstract}

apolipoprotein VLDL-II / chicken / hen / egg production rate / lipid

Résumé - Apolipoprotéinie VLDL-ll plasmatique et production d'œufs chez la poule pondeuse. Mise au point d'un test ELISA. Les changements du profil de l'apolipoprotéinie VLDL-I/ (apoII) dans le plasma par rapport à la concentration en lipides ont été caractérisés pendant la période de transition aboutissant à la phase de ponte chez des souches commerciales de poules pondeuses (Gallus domesticus). L'apo-ll a été isolée du plasma de poulets traités aux cestrogènes et un test rapide ELISA a été mis au point pour sa quantification. La sensibilité du test était de $5 \mathrm{ng} / \mathrm{ml}$ et les coefficients de variation inter-et intra-essais étaient respectivement de 4 et $8 \%$. Alors que l'apo-ll n'a pu être détectée dans le plasma sanguin de poulets immatures, son taux augmentait légèrement jusqu'à 23 sem puis brutalement au début de la ponte. Ce profil reflète les très fortes modifications du métabolisme lipidique au début de la ponte et coincide avec le profil des lipides plasmatiques totaux et avec le taux de production d'œufs. Les apo-ll plasmatiques de 2 souches des poules pondeuses diffèrent par le poids corporel mais, comparées à des taux de ponte similaires, tendaient à être plus élevées chez la souche la plus lourde. II a été conclu que l'ovogenèse est le principal facteur influant à la fois sur les profils en apo-ll et en lipides totaux plasmatiques chez le poulet, permettant ainsi un apport efficace de VLDL à l'œuf.

apolipoprotéinie VL DL-II / poulet / souche / taux de production d'œufs / lipides 


\section{INTRODUCTION}

The onset of lay in chickens is accompanied by estrogen-induced hepatic lipogenesis, resulting in hyperlipidemia in the plasma of laying hens (Hermier et al, 1989). Triglyceride concentration, for example, increases from $0.5-1.5 \mu \mathrm{mol} / \mathrm{ml}$ of plasma prior to lay to $20-50 \mu \mathrm{mol}(\mathrm{ml})$ at the onset of lay (Griffin and Hermier, 1988). This higher concentration persists in the plasma as long as hens remain in lay, and contains 2 major laying-hen-type lipoproteins as yolk precursors: very low density lipoprotein (VLDL) and vitellogenin (Burley et al, 1993). In the laying hen, VLDL particles contain large amounts of apolipoprotein VLDL-II (apo-II) in addition to apoB (Burley et al, 1984; Dugaiczyk et al, 1993). These triglyceride-rich lipoproteins are primarily transported from the liver to the growing oocytes (Hermier et al, 1989).

In an attempt to discover its function, Nimpf and coworkers (1988) disproved receptor-mediated endocytosis in oocytes by apo-II, but later demonstrated inhibitory properties of apo-II on lipoprotein lipase (LPL) activity (Schneider et al, 1990). They suggested that the presence of apo-II in laying-hen VLDL ensures efficient delivery of triglycerides to the oocyte for subsequent use as an energy source by the embryo.

In view of the above findings, and to ascertain this hypothesis under physiological conditions, in the present study we characterized the developmental pattern of apoII in the plasma with regard to lipid content at the onset of lay. Using the procedure developed for the purification of apo-II (Nimpf et al, 1988), we isolated pure apo-II from the plasma of estrogen-administered roosters, and developed a rapid ELISA for its quantification in chickens. We then compared the concentration of apo-Il in the plasma of hens with different inherent tendencies for egg production.

\section{MATERIALS AND METHODS}

\section{Purification of apo-II}

Leghorn roosters were administered with a single intra-muscular injection of $\beta$-estradiol-3-benzoate (Sigma, $50 \mathrm{mg} / \mathrm{ml}$ corn oil) at level of $50 \mathrm{mg} / \mathrm{kg}$ body-weight. Blood was collected from the heart with EDTA-containing syringe $(2 \mathrm{mg} / \mathrm{ml})$ as an anticoagulant. The blood was kept cool $\left(0-4^{\circ} \mathrm{C}\right)$, centrifuged $(1500 \mathrm{~g}, 20 \mathrm{~min})$ and the plasma was separated. VLDL was purified after centrifugation at $18500 \mathrm{~g}, 23 \mathrm{~h}$ and the apo-II was isolated from the VLDL as described by Nimpf et al (1988). The purified apo-Il was dissolved in buffer containing $75 \mathrm{mM} \mathrm{NaCl}, 50 \mathrm{mM}$ Tris- $\mathrm{HCl}$, and 60 $\mathrm{mM}$ octylglucoside, $\mathrm{pH} 7.4$, to give a final protein concentration (Bradford, 1976) of $1 \mathrm{mg} / \mathrm{ml}$. The purified apo-II was separated on an SDS-polyacrylamide gel and identified by immunoblotting. This was compared to a purified apo-II which was kindly provided by Dr Schneider (Vienna, Austria) (Nimpf et al, 1988).

\section{Preparation of polyclonal antibodies}

Polyclonal antibodies for measuring plasma apoII levels were prepared according to the recommendations of the committee on apolipoproteins, the International Federation of Clinical Chemistry (IFCC) (Marcovina et al, 1990a, 1990b). Polyclonal antibodies were raised in male white albino rabbits by 4 subcutaneous injections of pure apoII solution ( $150 \mu \mathrm{g}$ per rabbit) at 2-week intervals. The first injection was carried out using incomplete adjuvant $(1: 1, v: v)$, the next 3 injections with complete adjuvant. Sera from the immunized rabbits were screened for reactivity against the antigen following each injection and antisera were harvested.

\section{Electrophoretic procedure}

Electrophoresis was performed on a 1 dimensional (100 mm long, $1.5 \mathrm{~mm}$ thick) SDS-polyacrylamide gel (12 $\mathrm{g} / 100 \mathrm{ml}$ ) (SDS-PAGE) according to Laemmli (1970). Protein bands were stained with Coomassie Brilliant Blue, or subjected to Western blotting. 


\section{Immunoblotting procedure}

Separated proteins were electrophoretically transferred to nitrocellulose sheets (Towbin et al, 1979) using a Western immunoblotting system (Trans Blot, Bio-Rad). The electrotransferred proteins were incubated with rabbit anti-chicken apo-II, diluted 1: $1000,(v / v)$ in TBS, for $18 \mathrm{~h}$ at room temperature. Following two 10-min washes in TBS, the nitrocellulose sheets were incubated with a goat anti-rabbit antibody conjugated to heavy-andlight-chain $(\mathrm{H}+\mathrm{L}$ ) peroxidase as a substrate (BioMakor, Israel), for $2 \mathrm{~h}$ at room temperature. Staining was performed with $0.25 \%$ 4-chloro-1-naphthol (Merck) in $20 \%$ methanol and $0.1 \% \mathrm{H}_{2} \mathrm{O}_{2}$, and stopped after $5 \mathrm{~min}$ with distilled water.

Bands of plasma samples and the purified apo-II were scanned in a densitometer, using densitometry computer software for proteins quantification (W360, Hoefer Scientific Instruments, CA, USA).

\section{Measurement of plasma apo-II by ELISA}

Competitive ELISA was performed with unknown amounts of plasma apo-II. The primary polyclonal antibody used was raised against apo-ll purified from estrogenized rooster plasma (rabbit antichicken $\lg G$ ) and was detected with goat anti-rabbit antibody. In brief, 96-well immunoplates (Nunc, Kamstrup, Denmark) were coated overnight at $4^{\circ} \mathrm{C}$ with $200 \mu \mathrm{l} /$ well of plasma diluted $10^{6}$-fold in carbonate-bicarbonate buffer $(\mathrm{pH}$ 9.6). The wells were then washed 3 times ( 5 min each) with a PBS washing solution ( $\mathrm{pH} 7.6$ ) containing $0.05 \%$ Tween. Rabbit anti-apo-ll antibody (diluted 1: 1000) was added $\left(100 \mu \mathrm{l} /\right.$ well) and incubated for $1 \mathrm{~h}$ at $37^{\circ} \mathrm{C}$, followed by washing, as described above. Then $100 \mu$ l goat anti-rabbit IgG (diluted 1: 2000 ) peroxidase conjugate (Bio-Makor) was added to each well and incubated for $1 \mathrm{~h}$ at $37^{\circ} \mathrm{C}$. After washing, the bound antibodies were detected by adding $40 \mu \mathrm{l}$ 2,2'-azino-bis(3-ethylbenzthiazoline sulfonate peroxidase) substrate (KPL, MD). The plate was read after $5 \mathrm{~min}$ in a microplate reader (Bio-Tek Instruments, Burlington, VT) at $405 \mathrm{~nm}$.

\section{Calibration of a standard curve}

Each assay also included duplicate samples of the purified apo-Il ( 0 to $0.312 \mu \mathrm{g} / \mathrm{ml}$ ) as a standard curve, and plasma from layers and roosters (Leghorn) as references. Rooster plasma was confirmed to be devoid of apo-ll and used as a blank. Plasma samples $(10 \mu \mathrm{l})$ were applied at a $10^{6}$-fold dilution.

\section{Egg production and apo-ll of broiler- breeder-hen animals and husbandry}

Forty commercial broiler breeder females (Arbor Acres) were reared from hatch to 50 weeks of age under practical management conditions. They were provided commercial diets via restricted feeding regimens until 17 weeks of age. At 18 weeks of age, 22 birds were randomly selected and placed in individual cages in a 2-stair-step laying battery. A commercial breeder diet was given daily $(08.00-10.00 \mathrm{~h})$ in restricted amounts, which varied with age and production status. The birds had free access to water. Natural daylight (9-11 h) was provided until 23 weeks of age, and a 16-h photoperiod, supplemented with artificial light, was maintained thereafter. Body weights were recorded every second week, throughout the experimental period. Eggs from individual hens were collected and weighed daily, and production rate was determined on a weekly basis. Egg components were determined; the egg was broken and the yolk was removed and weighed. Birds were bled several times during the experimental period.

\section{Apo-II in egg-type hens}

A commercial egg-type flock (Lohmann) in the second cycle of the laying period was kept in indjvidual battery cages and treated under practical management conditions. Eggs from 12 individual hens were collected daily and production rate was determined. Hens were bled once a month.

\section{Blood collection and measurements}

Blood was collected with a heparinized syringe from the jugular vein of 5 birds each month. The blood was kept cool $\left(0-4^{\circ} \mathrm{C}\right)$, centrifuged (1500 $g, 10 \mathrm{~min}$ ) and the plasma was collected and kept at $-20^{\circ} \mathrm{C}$ till chemical analysis. Total lipid content was determined by sulfophosphovanillin 
reaction (Zoellner and Kirsch, 1962). Plasma apo-II was determined by ELISA as described above.

\section{Statistical analysis}

The statistical model used consisted of a factorial design in which lines and diets were assigned as main effects. Analysis of variance was carried out using the General Linear Models (GLM) procedure of base SAS software (1985).

\section{RESULTS}

SDS-PAGE of the purified apo-II revealed 2 protein bands at molecular weights closely approximating those of the mono- and dimeric forms of apo-II found previously ( 9 500 and 16 000, respectively (Nimpf et al,

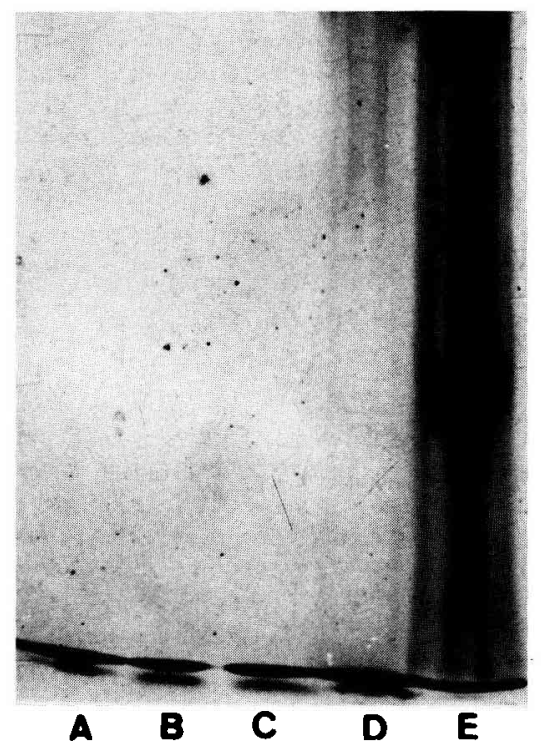

Fig 1. SDS-PAGE separation (10 $\mu \mathrm{g}$ each) of: lane A, apo-II; lanes B and $C$, apo-II purified as described in Materials and methods; lane D, VLDL of estrogen-administered roosters; and lane $E$, plasma $(10 \mu l)$ of estrogen-administered roosters.
1988) (fig 1). The bands of the purified apoII (lanes $B$ and C) migrated in a similar way to that provided by Schneider (lane A). Except for the plasma sample (lane E), which was run in its non-reduced form, all other samples displayed both the monoand dimetric forms.

Samples of blood plasma from chickens were separated by SDS-PAGE (fig 2). Whereas cockerel plasma (lane A) was

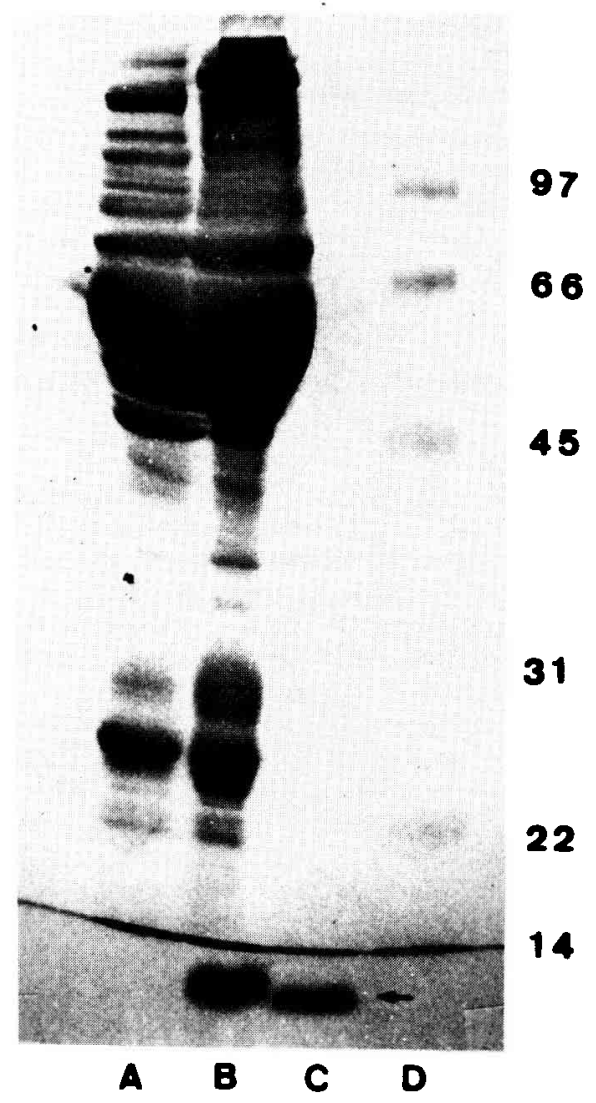

Fig 2. SDS-PAGE of blood plasma proteins (2.5 $\mu l$ per lane): lane A, cockerel; lane B, layer hen; lane $\mathrm{C}$, purified apo-II (5 $\mathrm{g}$ g protein); and lane D, prestained SDS-PAGE standards, consisting of phosphorylase B (97.4 kDa), bovine serum albumin (66.2 kDa), ovalbumin (45 kDa), carbonic anhydrase ( $31 \mathrm{kDa})$, soybean trypsin inhibitor (21.5 kDa), and lysozyme (14.4 kDa). 
devoid of apo-II, large amounts of it could be found in layer hen plasma and purified apoII (lanes B and C, respectively).

Immunoblot analysis of the purified apoII and chicken plasma samples also revealed the 2 bands of apo-ll (fig 3 ). Whereas cockerel plasma samples (lanes $A$ and $E$ ) were again devoid of apo-II, those of layers (lanes B and F) had large amounts of it.

\section{Standard curve of apo-I/ by ELISA}

Percent binding of antibodies increased with increasing amounts of purified apo-Il, reaching a plateau at $0.3 \mu \mathrm{g} / \mathrm{ml}$ for both exposure times (fig 4A). Samples exposed to substrate for $1 \mathrm{~min}$ bound about half of those exposed for $5 \mathrm{~min}$. At both exposure times,

\section{6}

31

\section{8.}

22

14

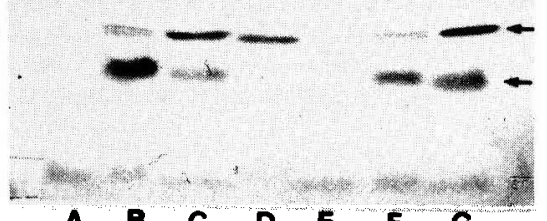

Fig 3. Immunoblot analysis of purified apo-II and blood plasma proteins: lane A, cockerel plasma $(2.5 \mu \mathrm{l})$; lane $\mathrm{B}$, layer-hen plasma $(2.5 \mu \mathrm{l})$; lane $\mathrm{C}$, purified apo-II (2.5 $\mu$ g protein); lane D, prestained SDS-PAGE standards; lane E, cockerel plasma (1.25 $\mu \mathrm{l})$; lane $F$, layer-hen plasma (1.25 $\mu \mathrm{l})$; and lane $\mathrm{G}$, purified apo-ll ( $5 \mu \mathrm{g}$ protein). Standards were: ovalbumin ( $45 \mathrm{kDa}$ ), carbonic anhydrase (31 kDa), soybean trypsin inhibitor $(21.5 \mathrm{kDa})$, and lysozyme (14.4 kDa). a linear relationship ( $r=0.99)$ was observed when data were plotted on log-to-log scales (fig 4B). In order to minimize variation in color development due to differences in exposure time between samples on a plate, only the 5-min time point was used in further analyses. The sensitivity of this assay was $5 \mathrm{ng} / \mathrm{ml}$, and the inter- and intra-assay coefficients of variation were 4 and $8 \%$, respectively.

\section{Calibration of the ELISA}

A primary standard (the purified apo-II, fig 4) and reference materials were run and compared in each ELISA. The latter consisted of a predetermined amount of apo-ll from the plasma of a layer hen (quantified by immunoblotting, fig 3), and cockerel plasma as a blank (devoid of apo-II). Quantification of the apo-II bands on the immunoblot (fig 3 ) with the corresponding ELISA indicated that the reference material, ie layerhen plasma, contained approximately 1700 $\mu \mathrm{g}$ apo-Il per $\mathrm{ml}$.

\section{Apo-II in broiler-breeder hens}

Egg production rate peaked at 26 weeks of age and decreased slightly thereafter (fig 5A). In contrast, egg weight (fig 5B) and the relative amount of egg yolk (fig $5 \mathrm{C}$ ) increased with age during the experimental period. Plasma lipid level ranged around $7 \mathrm{mg} / \mathrm{ml}$ during the growing period (fig 5D). Corresponding to the onset of lay, a sharp rise in lipid levels was observed at 23 weeks of age, decreasing slightly thereafter. No measurable levels of apo-ll could be detected in the blood plasma at 4 weeks of age. However a level of $500 \mu \mathrm{g} / \mathrm{ml}$ was observed between 12 and 23 weeks of age. The level increased 4-fold at the onset of lay and stabilized thereafter. The apoII/lipid $(\mu \mathrm{g} / \mathrm{mg})$ ratio in the plasma ranged 
A

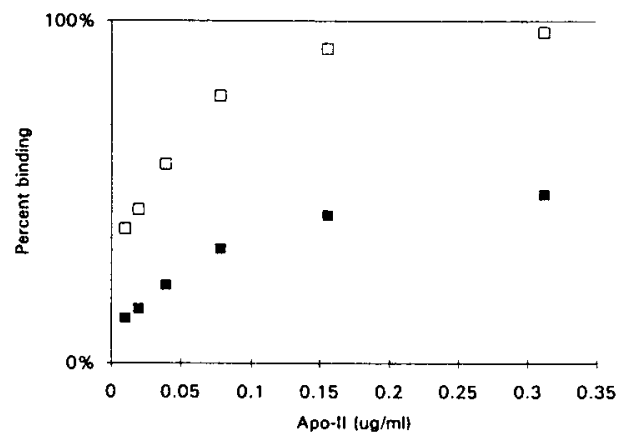

$\mathbf{B}$

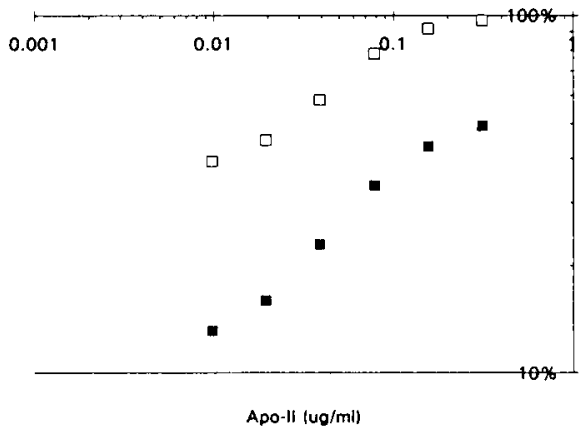

Fig 4. Relationship between purified chicken apo-II concentration and \% binding of antibodies on linear (A) and logarithmic (B) scales as detected by ELISA. Exposure times: $1 \mathrm{~min}(\square)$ and $5 \mathrm{~min}(\square)$.

around $60-70$ until 30 weeks of age, and increased with age thereafter (fig $5 \mathrm{~F}$ ).

\section{Apo-Il in egg-vs meat-type hens}

Egg production rate ranged from 63 to $70 \%$ and did not differ statistically between meatand egg-type hens. However, the body weight of the meat-type hens was about 2fold higher than that of their egg-type counterparts (table I). Plasma apo-II was slightly higher in meat- vs egg-type hens, to a statistical degree with the 100-week hens $(P<$
$0.02)$ than with those sampled at 104 weeks of age $(P<0.07)$.

\section{DISCUSSION}

Apo-II, an apolipoprotein, which is unique to avian species and is expressed during the laying cycle, has been extensively investigated (Burley et al, 1984; Nimpf et al, 1988; Hermier et al, 1989; Schneider et al, 1990; Barber et al, 1991; Dugaiczyk et al, 1993; Wijnholds et al, 1993). Estrogen induction of apo-II biosynthesis (Burley et

Table I. Body weight, egg production rate and level of apo-Il in the plasma of laying hens, sampled from egg- and meat-type strains.

Egg-type Egg-type Meat-type

$\begin{array}{llll}\text { Age (weeks) } & 100 & 104 & 33 \\ \text { Body weight (g) } & 1760 \pm 24 \mathrm{~b} & & 3840 \pm 30^{\mathrm{a}} \\ \text { Egg production rate (eggs/d) } & 0.63 \pm 0.06 & 0.70 \pm 0.03 & 0.69 \pm 0.05 \\ \text { Apo- } 11(\mu \mathrm{g} / \mathrm{ml}) & 1498 \pm 177^{\mathrm{b}} & 1700 \pm 246 \text { ab } & 2126 \pm 171^{\mathrm{a}}\end{array}$

Data are means $\pm S E$ of 12 and 5 hens for egg- and meat-type chickens, respectively. ab Rows with different superscript letters are significantly different $(P<0.02)$. 
A

D

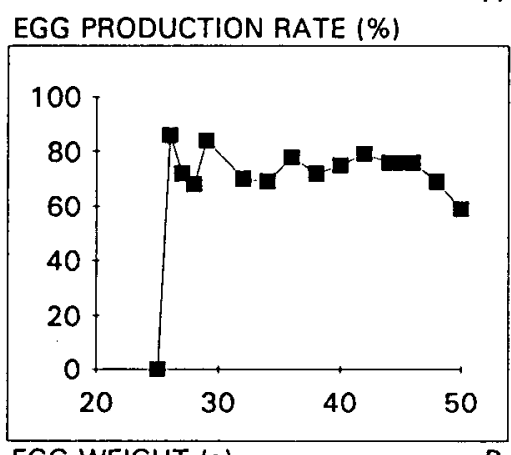

PLASMA TOTAL LIPID $(\mathrm{mg} / \mathrm{mL})$
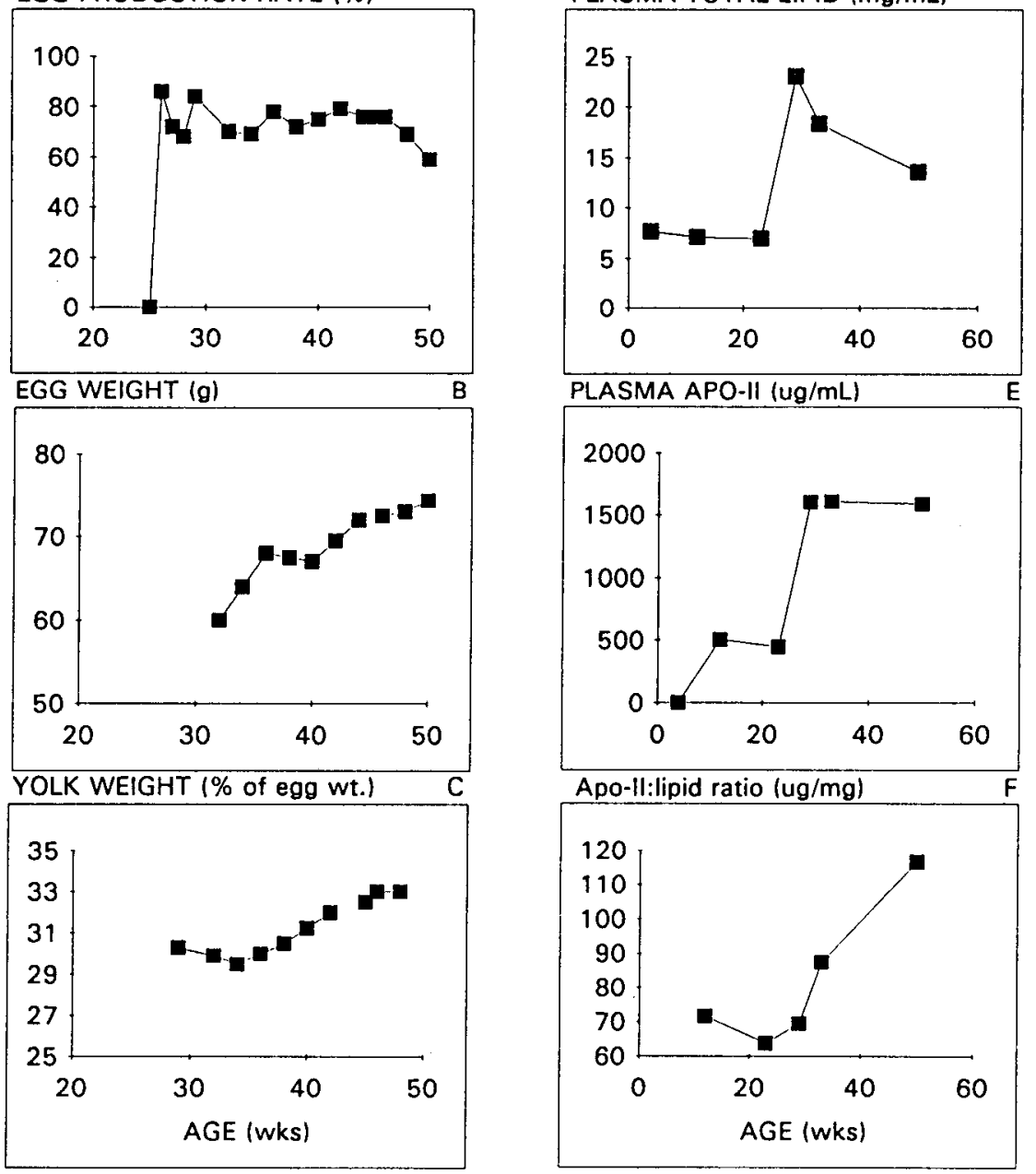

Fig 5. Egg production rate $(A)$, egg weight $(B)$, relative yolk weight $(C)$, the concentrations of blood plasma total lipid (D), plasma apo-II (E) and the ratio between them (F) with age, in commercial broiler breeder hens.

al, 1984; Nimpt et al, 1988; Hermier et al, 1989), concurrent with dramatic changes in lipid metabolism at the onset of lay, eg, increases in hepatic lipogenesis and in the production of egg yolk precursors (Burley et al, 1993), indicated its role in oogenesis.
Recent investigations by Nimpf et al (1988) have disproven any functional receptormediated endocytosis in the oocyte by apoII. However, the inhibitory properties of apoII on LPL activity found in vitro (Schneider et $a l, 1990$ ) suggest that the presence of apo- 
II on laying-hen VLDL ensures efficient delivery of triglycerides to the oocyte for subsequent use as an energy source by the embryo. In view of the latter findings, and to validate this hypothesis under physiological conditions, we characterized the developmental pattern of plasma apo-11 with regard to lipid content during the transition from juvenile to oogenic mature laying hens. Using the procedure developed to isolate purified apo-Il (Nimpf et al, 1988), we obtained pure apo-II from the plasma of estrogen-administered roosters, and developed a rapid ELISA for its quantification.

Apo-II is an apolipoprotein with a molecular weight of about 9600 . In native lipoproteins it exists as a dimer linked by a single disulfide bond (Griffin and Hermier, 1988). In the present study, it appeared as 2 protein bands following SDS-PAGE (fig 1) or Western blotting (fig 3). Our isolated apo-11 migrated in a similar way to that provided by Schneider (fig 1, lane A), confirming its purity.

It is generally agreed that expression of the apo-Il gene in layer chickens depends on estrogen (Burley et al, 1984; Cochrane and Deeley, 1988; Griffin and Hermier, 1988; Nimpf et al, 1988; Douaire et al, 1990; Berkowitz et al, 1993). Indeed, rooster plasma was found by Western blot to be devoid of apo-II, in contrast to laying hens, which had a very high amount of it. Because the amount of an isolated lipoprotein has been reported to be different from its amount in the plasma in its native form (Barkia, 1990), the accuracy of any immunoassay depends on the use of a suitable primary standard, as well as reference material for calibration. Therefore, each ELISA in the present study was performed with the use of a primary standard (fig 4) and plasma from layers and cockerels as reference materials.

Whereas no detectable levels of apo-II could be monitored in the blood plasma of immature chickens (to 12 weeks of age) (fig
5), a slight increase in the level of apo-ll was observed in females prior to 23 weeks of age, with a sharp rise at the onset of lay. Furthermore, the developmental patterns of plasma apo-II and total lipids were similar, both increasing by 3 to 4 -fold at the onset of lay (fig 5). This is presumably due to increases in the estrogenic activity of chickens upon transition to the reproductive cycle. Expression of the apo-ll gene, which is restricted to the liver, is absolutely dependent on estrogen and normally occurs only during periods of egg laying (Berkowitz et al, 1993). Apo-II, along with other eggyolk precursor proteins, has been shown to be induced in birds by estrogen, primarily due to increased transcription of the gene (Cochrane and Deeley, 1988). In contrast to plasma total lipid which declined with age and egg production, apo-I! levels remained unchanged. This finding is further demonstrated by the apo-Il/lipid ratio, which increased consistently with age (fig $5 F$ ). This could be explained by a lower estrogeninduction threshold for apo-II vs lipid biosynthesis induction. Although plasma estrogen was not monitored, it may be speculated that the estrogen-dependent expression of apo-ll biosynthesis differs from that of lipids.

To compare the level of apo-II in the blood plasma of egg- vs meat-type strains, hens exhibiting approximately similar egg production rates were examined (table l). The production rate ranged between 63 and $70 \%$ but did not differ statistically, despite the 2-fold difference in body weight. Plasma apo-II, however, was slightly higher in meatvs egg-type hens, to a statistical degree with the 100-week hens $(P<0.02)$ than those sampled at 104 weeks of age $(P<0.07)$. If these findings are real it may be speculated that oogenesis is the main factor affecting both apo-II and total lipid profiles in the plasma of chickens, enabling efficient delivery of VLDL to the egg. Strain differences seem to occur, regardless of production phase. However, further studies are needed 
to elucidate whether the strain difference shown here is a consequence of physiological differences in lipid metabolism, or an artifact due to the comparison between different ages.

\section{ACKNOWLEDGMENTS}

We thank WJ Schneider (Vienna, Austria) for providing apo-Il. This research was supported in part by grants from the Egg and Poultry Marketing Board of Israel.

\section{REFERENCES}

Barber DL, Sanders EJ, Aebersold R, Schneider WJ (1991) The receptor for yolk lipoprotein deposition in the chicken oocyte. J Biol Chem 266, 18761-18770

Barkia A (1990) What do we know about apo A-I containing lipoproteins? Ann Biol Clin Paris 48, 529-535

Berkowitz EA, Chu WW, Evans MI (1993) Insulin inhibits the estrogen-dependent expression of the chicken very low density apolipoprotein-II gene in leghorn male hepatoma cells. Mol Endocrinol 7, 507-514

Bradford MM (1976) A rapid and sensitive method for the quantification of microgram quantities of protein using the principle of dye binding. Anal Biochem 72 , 248-254

Burley RW, Sleigh RW, Sherstone FS (1984) Lipoproteins from the blood and egg yolk of the hen. The transfer of very-low-density lipoprotein to egg yolk and possible changes to apoprotein B. Eur $J$ Biochem 142, 171-176

Burley RW, Evans AJ, Pearson JA (1993) Molecular aspects of the synthesis and deposition of hens' egg yolk with special reference to low density lipoprotein. Poult Sci 72, 850-855

Cochrane AW, Deeley RG (1988) Estrogen-dependent activation of the avian very low density apolipoprotein II and vitellogenin genes: transient alterations in mRNA polyadenylation and stability early during induction. J Mol Biol 203, 555-567

Douaire M, Langlois P, Flamant F, Mallard J (1990) ApoVLDLIl gene transcription in immature cockerels without estradiof stimulation. Comp Biochem Physiol $[A] 97,55-58$

Dugaiczyk A, Inglis AS, Strike PM, Burley RW, Beattie WG, Chan $L$ (1993) Comparison of the nucleotide sequence of cloned DNA coding for an apolipopro- sequence of cloned DNA coding for an apolipoprotein (apoVLDL-II) from avian blood and the aminoacid sequence of an egg-yolk protein (apoviteilenin 1): equivalence of the two sequences. Gene 14, 175182

Griffin HD, Hermier D (1988) Plasma lipoprotein metabolism and fattening in poultry. In: Leanness in Domestic Birds (B Leclercq, CC Whitehead, eds) Butterworth, London, UK

Hermier D, Forgez P, Williams J, Chapman MJ (1989) Alterations in plasma lipoproteins and apolipoproteins associated with estrogen-induced hyperlipidemia in the laying hen. Eur J Biochem 184, 109118

Laemmli UK (1970) Cleavage of structural proteins during assembly of the head of bacteriophage T4. Nature (Lond) 227, 680-685

Marcovina S, Curtiss LK, Milne R, Albers JJ (1990a) International Federation of Clinical Chemistry (IFFCC), scientific division, committee on apolipoproteins, working group on antibody reagents, selection and characterization of monoclonal antibodies for measuring plasma levels of apolipoproteins-A-I and apolipoproteins-B. Ann Biol Cin Paris 48, 597-600

Marcovina S, Curtiss LK, Milne R, Albers JJ (1990b) International Federation of Clinical Chemistry (IFCC), scientific division, committee on apolipoproteins, working group of antibody reagents, selection and characterization of monoclonal antibodies for measuring plasma levels of apolipoproteins-A-I and apoliproteins-B. J Autom Chem 12, 195-198

Nimpf J, George R, Schneider WJ (1988) Apolipoprotein specifity of the chicken oocytes receptor for low and very low density lipoproteins: lack of recognition of apolipoprotein VLDL-II. J Lipid Res 29, 657667

SAS Institute (1985) SAS User's Guide: Statistics. SAS Institute Inc, Cary, NC

Schneider WJ, Carroll R, Severson DL, Nimpf J (1990) Apolipoprotein VLDL-II inhibits lipolysis of triglyceride-rich lipoproteins in the laying hen. $J$ Lipid Res 31, 507-513

Towbin H, Staehelin T, Gordon G (1979) Electrophretic transfer of proteins from polyacrylamide gels to nitrocellulose sheets: procedure and some applications. Proc Natl Acad Sci USA 76, 4350-4354

Wijnholds J, Philipsen S, Pruzina S, Fraser P, Grosveld $F, A b G$ (1993) Estrogen-inducible and liver-specific expression of the chicken very low density apolipoprotein-II gene locus in transgenic mice. Nucleic Acids Res 21, 1629-1635

Zoellner N, Kirsch K (1962) Determination of lipids (micromethod) by means of the sulfophosphovanillin reaction common to many natural lipids (all known plasma lipids). Z Gesamte Exp Med 135, 545-561 